\title{
BODY WATER AND SODIUM IN PATIENTS WITH ACROMEGALY ${ }^{1}$
}

\author{
BY DENIS IKKOS, ROLF LUFT, AND BJÖRN SJÖGREN \\ (From the Division of Endocrinology of the Department of Internal Medicine, \\ Serafimerlasarettet, Stockholm, Sweden)
}

(Submitted for publication December 1, 1953; accepted March 2, 1954)

The acromegalic state often is accompanied by an enlargement of the soft tissues of the body. The purpose of the present work was to determine whether these tissue changes are accompanied by changes in the content and distribution of water and electrolytes in the body. In this connection the administration of growth hormone was shown to induce an increase in the total body water of normal (1-4) and hypophysectomized (5) rats, and of normal dogs and cats (3). Similarly, growth hormone caused a retention of sodium and potassium in normal (6) and diabetic (7) rats, and a retention of sodium, potassium, and chloride in adrenalectomized rats (8). The thiocyanate space in normal and hypophysectomized rats (9) and the plasma volume in dogs (10) increased after injection of growth hormone.

The present paper gives the results of measurements of the total body water, the extracellular water and the exchangeable sodium in 18 acromegalic patients.

\section{MATERIAL AND METHODS}

Total body water was calculated from the volume of distribution of antipyrine (11). Total exchangeable sodium was calculated from the apparent volume of distribution of the radioactive sodium isotope $\mathrm{Na}^{24}$ (12). The extracellular water was calculated from the volumes of distribution of inulin (13) or thiosulfate (14). In six cases, both of these methods were used to estimate the volume of extracellular water. In six cases, no measurement of the extracellular fluid was made.

All experiments started at 8 a.m. The patients were not allowed to eat after 8 p.m. the day before the test. Urine was collected the preceding day for the determination of the blank excretion of inulin. The antipyrine was given from a calibrated burette, and venous blood samples were drawn after two, three, four, and five hours. Immediately after the injection of antipyrine the constant infusion of inulin was started. The infusion of inulin was continued for 6 to 7 hours. When simultaneous

1 These studies were aided by grants from the Medical Research Council of Sweden and from Knut and Alice Wallenberg's Foundation. measurements of the thiosulfate and inulin spaces were performed, thiosulfate was injected immediately after the inulin test was completed. If the thiosulfate space only was used for the measurement of the extracellular water, the test was performed the day after the determination of total body water, since thiosulfate interferes with the chemical analysis of antipyrine in plasma.

Radioactive sodium, $\mathrm{Na}^{24}$, was injected intravenously, immediately after the determination of the extracellular water was completed. Urine was collected for the following 18 hours, and blood samples were taken at the end of the urine collection period.

Antipyrine in plasma was analyzed according to Brodie, Axelrod, Soberman, and Levy (15). In our hands the time necessary for the completion of the reaction between antipyrine and sodium nitrite was different from day to day. Repeated readings, therefore, were taken every five to ten minutes after the addition of sodium nitrite. The maximal extinctions obtained were plotted on a semilogarithmic paper, and the extinction at zero time was obtained by extrapolation. The volume of distribution of antipyrine was calculated by dividing the given amount of antipyrine by its zero time plasma concentration.

The inulin in plasma was analyzed by Roe's resorcinol method, as modified by Schreiner (16). The inulin space was obtained by dividing the total amount of inulin excreted after discontinuation of the infusion by the inulin concentration in plasma at equilibrium. The thiosulfate in plasma was analyzed by the indirect iodometricmacromethod of Newman, Gilman, and Philips (17). The thiosulfate concentration at zero time was obtained by extrapolation, and the volume of distribution calculated from this value and the amount of thiosulfate given.

The concentration of sodium in plasma was measured by a Beckman flame photometer.

The conversion of the antipyrine, inulin, and thiosulfate spaces to total body water and extracellular water, respectively, was made by multiplying the values obtained by 0.93 . The concentration of sodium in plasma water was calculated from the corresponding value in plasma, using the same figure, 0.93 . The plasma water content of the acromegalic patients was taken as normal.

The surface area of the body was derived from the nomogram of DuBois, although the authors are aware of the fact that the applicability in acromegaly of the DuBois surface area tables has not been proved.

Intracellular water was taken as the difference between total body water and extracellular water. Total ex- 
TABLE I

Case material

\begin{tabular}{|c|c|c|c|c|c|c|c|c|c|c|c|}
\hline \multirow[b]{2}{*}{$\begin{array}{c}\text { Case } \\
\text { no. }\end{array}$} & \multirow[b]{2}{*}{ Patient } & \multirow[b]{2}{*}{$\begin{array}{c}\text { Age } \\
\text { years }\end{array}$} & \multirow[b]{2}{*}{ Sex } & \multirow[b]{2}{*}{$\begin{array}{c}\text { Height } \\
\text { cm. }\end{array}$} & \multirow[b]{2}{*}{$\begin{array}{c}\text { Weight } \\
\boldsymbol{K}_{\boldsymbol{g}} .\end{array}$} & \multirow[b]{2}{*}{$\begin{array}{c}\text { Surface } \\
\text { area } \\
m^{2}\end{array}$} & \multirow[b]{2}{*}{$\begin{array}{c}\text { Duration } \\
\text { of } \\
\text { disease } \\
\text { years }\end{array}$} & \multirow[b]{2}{*}{$\begin{array}{c}\begin{array}{c}\text { Soft } \\
\text { tissue } \\
\text { swelling }\end{array} \\
\text { switis }\end{array}$} & \multicolumn{3}{|c|}{ Plasma phosphorus, mg. \% } \\
\hline & & & & & & & & & $\begin{array}{l}\begin{array}{l}\text { At the } \\
\text { present } \\
\text { study }\end{array} \\
\end{array}$ & $\begin{array}{c}\begin{array}{c}\text { Highest } \\
\text { value } \\
\text { observed* }\end{array}\end{array}$ & $\begin{array}{c}\text { Lowest } \\
\text { value } \\
\text { observed }\end{array}$ \\
\hline $\begin{array}{r}1 \\
2 \\
3 \\
4 \\
5 \\
6 \\
7 \\
8 \\
9 \\
10 \\
11 \\
12 \\
13 \\
14 \\
15 \\
16 \\
17 \\
18\end{array}$ & $\begin{array}{l}\text { S. K. } \\
\text { M. H. } \\
\text { D. P. } \\
\text { C. B. } \\
\text { E. E. } \\
\text { A. A. } \\
\text { A. F. } \\
\text { J. I. } \\
\text { L. H. } \\
\text { E. J. } \\
\text { M. M. } \\
\text { C. L. } \\
\text { S. A. } \\
\text { H. W. } \\
\text { K. L. } \\
\text { M.S. } \\
\text { I. B. } \\
\text { F. O. }\end{array}$ & $\begin{array}{l}36 \\
53 \\
35 \\
40 \\
23 \\
43 \\
42 \\
60 \\
23 \\
40 \\
42 \\
20 \\
49 \\
51 \\
52 \\
32 \\
30 \\
38\end{array}$ & $\begin{array}{l}\mathbf{M} \\
\mathbf{F} \\
\mathbf{F} \\
\mathbf{M} \\
\mathbf{F} \\
\mathbf{F} \\
\mathbf{M} \\
\mathbf{M} \\
\mathbf{M} \\
\mathbf{F} \\
\mathbf{F} \\
\mathbf{M} \\
\mathbf{F} \\
\mathbf{M} \\
\mathbf{M} \\
\mathbf{F} \\
\mathbf{M} \\
\mathbf{M}\end{array}$ & $\begin{array}{l}179 \\
164 \\
177 \\
181 \\
169 \\
156 \\
195 \\
175 \\
199 \\
165 \\
167 \\
197 \\
174 \\
175 \\
178 \\
173 \\
177 \\
182\end{array}$ & $\begin{array}{r}87.6 \\
68.0 \\
76.0 \\
101.0 \\
75.6 \\
63.0 \\
99.0 \\
80.8 \\
92.0 \\
74.0 \\
75.0 \\
95.0 \\
78.0 \\
80.0 \\
89.7 \\
78.0 \\
78.1 \\
92.5\end{array}$ & $\begin{array}{l}2.04 \\
1.73 \\
1.94 \\
2.20 \\
1.85 \\
1.61 \\
2.31 \\
1.95 \\
2.26 \\
1.81 \\
1.83 \\
2.28 \\
1.92 \\
1.95 \\
2.08 \\
1.90 \\
1.94 \\
2.12\end{array}$ & $\begin{array}{r}1 \\
10 \\
5 \\
10 \\
3 \\
10 \\
10 \\
30 \\
2 \\
3 \\
5 \\
2 \\
7 \\
15 \\
5 \\
5 \\
5 \\
10\end{array}$ & $\begin{array}{l} \pm \\
+ \\
+ \\
+ \\
+ \\
+ \\
\pm \\
\pm \\
\pm \\
+ \\
+ \\
+ \\
+ \\
+ \\
+ \\
+\end{array}$ & $\begin{array}{l}3.4 \\
4.0 \\
4.6 \\
3.9 \\
4.4 \\
3.7 \\
5.2 \\
3.6 \\
5.1 \\
3.3 \\
3.4 \\
5.6 \\
4.4 \\
3.4 \\
4.1 \\
5.8 \\
5.2 \\
4.5\end{array}$ & $\begin{array}{l}4.7 \\
4.6 \\
5.1 \\
4.7 \\
4.7 \\
5.6\end{array}$ & $\begin{array}{l}2.9 \\
3.7 \\
3.6 \\
4.3 \\
3.3 \\
3.3 \\
4.4\end{array}$ \\
\hline
\end{tabular}

* These values were observed during the whole period of observation.

changeable sodium (mEq.) was calculated from the apparent volume of distribution of radio-sodium $\mathrm{Na}^{24}$ (liters) and the concentration of sodium in the plasma water (mEq. per liter). Extracellular sodium was calculated as the product of plasma water sodium concentration (mEq. per liter) and extracellular water volume (liters). Intracellular sodium was calculated as the difference between total body sodium and extracellular sodium. The apparent mean intracellular sodium concentration (mEq. per liter) was calculated by dividing the intracellular sodium by the intracellular water volume.

The material of the present study consisted of 18 cases

TABLE II

Total body water and total exchangeable sodium in patients with acromegaly

\begin{tabular}{|c|c|c|c|c|c|c|c|c|}
\hline \multirow[b]{2}{*}{$\begin{array}{l}\text { Case } \\
\text { no. }\end{array}$} & \multicolumn{3}{|c|}{ Total body water } & \multirow{2}{*}{$\begin{array}{c}\text { Sodium } \\
m E_{q .} / L . \\
\text { plasma } \\
\text { water }\end{array}$} & \multicolumn{4}{|c|}{ Total exchangreable sodium } \\
\hline & $\boldsymbol{L}$. & $\begin{array}{c}\% \text { of } \\
\text { body } \\
\text { weight }\end{array}$ & 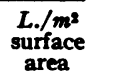 & & $m E q$. & $\begin{array}{c}m E_{q .} / K_{g} . \\
\text { body } \\
\text { weight }\end{array}$ & $\begin{array}{c}m E_{q .} / m^{2} \\
\text { surface } \\
\text { area }\end{array}$ & $\underset{\substack{m E_{q} / L \\
\text { total body }}}{\text { water }}$ \\
\hline $\begin{array}{r}1 \\
2 \\
3 \\
4 \\
5 \\
6 \\
7 \\
8 \\
9 \\
10 \\
11 \\
12 \\
13 \\
14 \\
15 \\
16 \\
17 \\
18\end{array}$ & $\begin{array}{l}49.6 \\
30.7 \\
41.0 \\
51.2 \\
34.0 \\
34.0 \\
63.1 \\
45.2 \\
54.8 \\
43.0 \\
35.8 \\
60.6 \\
40.1 \\
45.0 \\
55.5 \\
43.7 \\
43.6 \\
62.9\end{array}$ & $\begin{array}{l}\mathbf{5 6 . 6} \\
\mathbf{4 5 . 1} \\
\mathbf{5 2 . 7} \\
\mathbf{5 0 . 7} \\
\mathbf{4 5 . 0} \\
\mathbf{5 4 . 0} \\
\mathbf{6 3 . 7} \\
\mathbf{5 5 . 9} \\
\mathbf{5 9 . 6} \\
\mathbf{6 0 . 8} \\
\mathbf{4 7 . 7} \\
\mathbf{6 3 . 8} \\
\mathbf{5 1 . 4} \\
\mathbf{5 6 . 2} \\
\mathbf{6 1 . 9} \\
\mathbf{5 6 . 2} \\
\mathbf{5 5 . 8} \\
\mathbf{6 8 . 0}\end{array}$ & $\begin{array}{l}24.3 \\
17.8 \\
21.1 \\
23.3 \\
18.4 \\
21.1 \\
27.3 \\
23.2 \\
24.2 \\
24.9 \\
19.6 \\
26.6 \\
20.9 \\
23.1 \\
26.7 \\
23.0 \\
22.5 \\
29.7\end{array}$ & $\begin{array}{l}154 \\
151 \\
148 \\
154 \\
151 \\
151 \\
152 \\
151 \\
154 \\
152 \\
154 \\
151 \\
153 \\
153 \\
154 \\
154 \\
151 \\
149\end{array}$ & $\begin{array}{l}4,620 \\
3,956 \\
4,248 \\
\mathbf{5 , 4 5 2} \\
\mathbf{3 , 6 3 9} \\
\mathbf{3 , 4 1 3} \\
\mathbf{6 , 2 0 2} \\
\mathbf{4 , 6 5 1} \\
\mathbf{4 , 4 2 0} \\
\mathbf{3 , 5 8 7} \\
\mathbf{3 , 0 0 3} \\
\mathbf{5 , 5 2 7} \\
\mathbf{3 , 9 1 7} \\
\mathbf{4 , 7 1 2} \\
\mathbf{4 , 4 0 4} \\
\mathbf{3 , 7 8 8} \\
\mathbf{3 , 7 0 0} \\
\mathbf{4 , 8 4 3}\end{array}$ & $\begin{array}{l}\mathbf{5 2 . 7} \\
\mathbf{5 8 . 2} \\
\mathbf{5 4 . 6} \\
\mathbf{5 4 . 0} \\
48.1 \\
\mathbf{5 4 . 2} \\
\mathbf{6 9 . 7} \\
\mathbf{5 7 . 6} \\
\mathbf{4 8 . 0} \\
\mathbf{4 8 . 5} \\
\mathbf{4 0 . 0} \\
\mathbf{5 8 . 2} \\
\mathbf{5 0 . 2} \\
\mathbf{5 8 . 9} \\
\mathbf{4 9 . 1} \\
\mathbf{4 8 . 6} \\
\mathbf{4 7 . 4} \\
\mathbf{5 2 . 4}\end{array}$ & $\begin{array}{l}2,265 \\
2,287 \\
2,190 \\
2,478 \\
1,967 \\
2,120 \\
2,685 \\
2,385 \\
1,956 \\
1,982 \\
1,641 \\
2,424 \\
2,040 \\
2,416 \\
2,117 \\
1,994 \\
1,907 \\
2,284\end{array}$ & $\begin{array}{r}93.1 \\
128.8 \\
103.6 \\
106.4 \\
107.0 \\
100.4 \\
98.3 \\
102.9 \\
80.7 \\
79.7 \\
83.9 \\
91.2 \\
97.7 \\
104.7 \\
79.4 \\
86.7 \\
84.8 \\
77.0\end{array}$ \\
\hline \multirow{3}{*}{\multicolumn{2}{|c|}{$\begin{array}{l}\text { Average } \\
\text { Standard error of mean } \\
\text { Healthy subjects: } \\
\text { Average } \\
\text { Standard error of mean } \\
\text { Significance of difference: } \\
\text { P-value }\end{array}$}} & $\begin{array}{r}55.8 \\
1.5\end{array}$ & $\begin{array}{r}23.2 \\
0.7\end{array}$ & & & $\begin{array}{r}52.8 \\
1.5\end{array}$ & $\begin{array}{r}2,174 \\
60\end{array}$ & $\begin{array}{r}94.8 \\
3.1\end{array}$ \\
\hline & & $\begin{array}{r}49.7 \\
0.9\end{array}$ & $\begin{array}{r}18.6 \\
0.5\end{array}$ & & & $\begin{array}{r}37.1 \\
0.9\end{array}$ & $\begin{array}{r}1,386 \\
35\end{array}$ & $\begin{array}{r}74.7 \\
1.4\end{array}$ \\
\hline & & $<0.01$ & $<0.001$ & & & $<0.001$ & $<0.001$ & $<0.001$ \\
\hline
\end{tabular}


BODY WATER AND SODIUM IN PATIENTS WITH ACROMEGALY
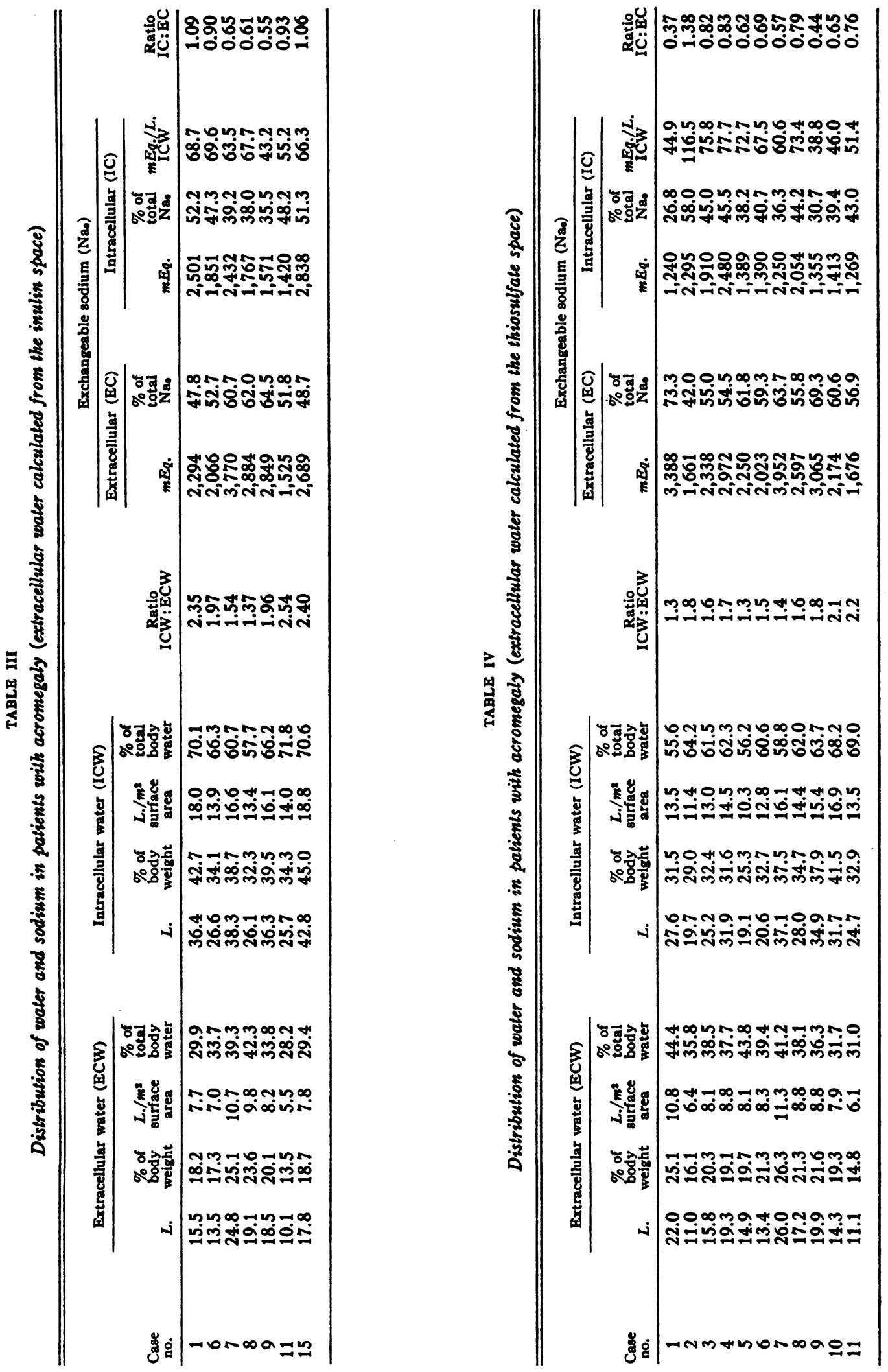
of acromegaly (Table I). In none of the patients thyrotoxicosis, diabetes mellitus, testicular atrophy or adrenal cortical insufficiency could be demonstrated. Signs of congestive heart failure were not present in any of the cases. No instances of acromegalic gigantism appeared in these patients. The cases were unselected with respect to the activity of the disease; cases Nos. 6, 11, and $\mathbf{1 5}$ were therefore included despite the fact that they were considered almost "cured." The table gives clinical and laboratory data, describing the status of the patients at the time of the present study.

\section{RESULTS}

In the acromegalics (Table II) the average total body water was found to be 55.8 per cent of the body weight or 23.2 liters per square meter of body surface. The corresponding figures for the normal group of nine healthy subjects (18) were 49.7 per cent and 18.6 liters, respectively. The differences between the figures of the two groups were statistically significant.

The amount of total exchangeable sodium in the acromegalics corresponded to $52.8 \mathrm{mEq}$. per $\mathrm{Kg}$. body weight or $2174 \mathrm{mEq}$. per square meter of surface area or $94.8 \mathrm{mEq}$. per liter of total body water. These figures were significantly higher than the corresponding ones in the group of healthy subjects.

The distribution of body water between the intra- and extracellular phases, using the inulin or thiosulfate spaces in the calculation of the amount of extracellular water, is presented in
Tables III and IV, respectively. In Tables III and IV is also presented the distribution of exchangeable sodium between the intra- and extracellular spaces using inulin or thiosulfate. The mean values of the results presented in Tables III and IV are given in Table $\mathrm{V}$ together with the corresponding figures obtained by similar measurements in the group of healthy subjects (18). Table V shows that extracellular water expressed as liters per square meter of surface area or as percentage of body weight was significantly increased in the acromegalics, whether the calculations were made from the inulin or thiosulfate spaces. However, when expressed as percentage of total body water, the extracellular water was significantly higher, only when the thiosulfate space was used.

The amount of intracellular water expressed as per cent of body weight was of the same magnitude in the acromegalics and in the healthy subjects. Expressed as liters per square meter of surface area it was different (higher) in the acromegalics, only when calculated from the inulin space. When expressed as per cent of total body water it was significantly higher in the acromegalics, only when calculated from the thiosulfate space.

The distribution of exchangeable sodium between the intra- and extracellular fluid compartments in the acromegalics did not differ from that in the healthy subjects. However, the "apparent" mean intracellular sodium concentration

TABLE V

A comparison of the distribution of water and exchangeable sodium in healthy subjects and acromegalics

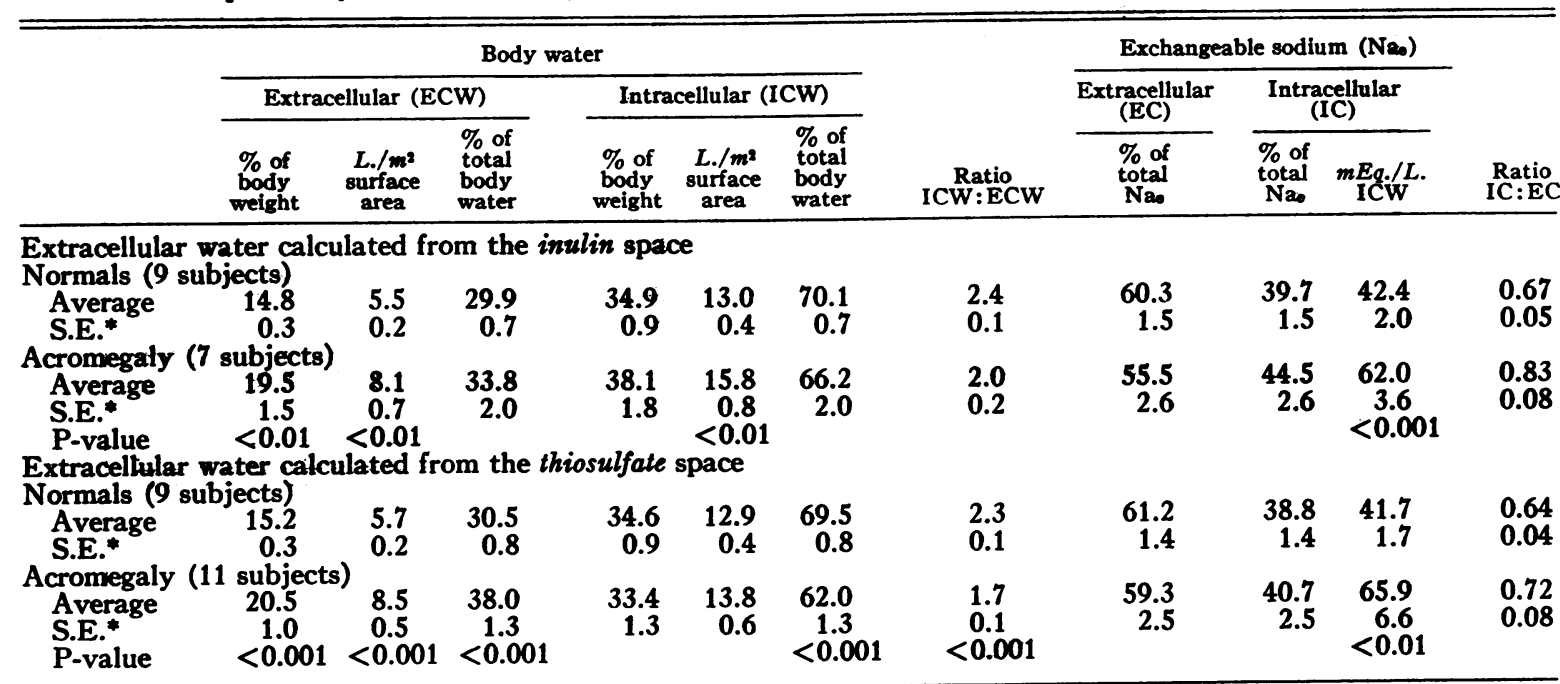

* Standard error of mean. 
was significantly higher in the acromegalic patients.

\section{DISCUSSION}

The question may be raised, whether, with the methods used, it is possible to obtain exact measurements of the total body water and extracellular water.

The antipyrine space in healthy subjects has been found to be 2 to 5 per cent smaller than the deuterium or tritium space $(11,19,20)$. The same relation was obtained in some diseased states (21) except in the presence of edema (22). This constancy shows that the antipyrine space represents at least a constant fraction of the total body water if not the true volume. In edematous patients the antipyrine space has been found to be about 15 per cent smaller than the deuterium space (22). No comparison has been made between the antipyrine and deuterium spaces in acromegaly. Whether the ratio of the antipyrine space to the deuterium space in acromegalics is smaller, as in edematous patients, or of the same magnitude as in healthy subjects, the significance of the differences found in the present work will still hold true.

It is very much discussed, whether the inulin and thiosulfate volumes of distribution represent the whole extracellular compartment. However, it has been shown that they measure a reproducible space, which is believed to be the functional extracellular fluid volume (23). Consequently, we have used the changes in the inulin and thiosulfate spaces as indices of changes in the extracellular compartment. "Extracellular water" in the present work therefore represents the portion of the true extracellular water, which is included in the inulin and thiosulfate space. From this it is obvious that the calculated "intracellular water" in the present work might be somewhat overestimated.

A better reference for the fluid compartments would perhaps be the correlation to the lean body mass. However, we did not consider the formulas developed for the calculation of the lean body mass a priori applicable to cases of acromegaly, where nothing is known about the mean water content of the lean body mass or the cell mass. In view of the abnormal body build in acromegaly we have correlated our results to body weight, surface area, and in the case of extracellular and intracellular water and exchangeable sodium also to total body water.

The finding of an increased total body water content in acromegalics is of interest in the light of the results obtained in the animal experiments mentioned in the introduction, as an abnormal secretion of growth hormone is generally believed to be, if not the only, at least the principal factor in the production of the clinical picture of acromegaly.

The increase in extracellular water in the acromegalics, when expressed as percentage of body weight or as liters per square meter of surface area, obtained with inulin as well as with thiosulfate, two substances so different in many respects, favors the view that the observed change in the extracellular water volume was a true increase and not due to alterations of the permeability of the cell membranes. Although the latter possibility cannot be excluded, the large increase in exchangeable sodium strongly favors the view that the extracellular space was increased.

The extracellular water represented a larger part of the total body water in the acromegalic than in the healthy subjects, but the difference was statistically significant with thiosulfate only. In three (Nos. 1, 11, and 15) of the seven patients studied with inulin the inulin space formed an entirely normal percentage of the total body water. Two of these cases (Nos. 11 and 15) had been treated for a long time and were considered almost "cured." Our results favor the hypothesis that in acromegaly the extracellular water is increased disproportionally to the intracellular water.

The increase in total exchangeable sodium observed in acromegaly was concomitant with the increase in the extracellular space. As to the observed increase in the "apparent" mean intracellular sodium concentration this finding does not prove an actual increase in the sodium content of the cells. It is known that about fifty per cent of the body sodium is to be found in the skeleton and that only about half of it exchanges with radiosodium in healthy subjects (24). An increase in the percentage of the bone sodium exchanged or a disproportional increase in the bone mass over the soft tissue would give an increased "mean intracellular sodium concentration."

The significance of the changes observed in the acromegalics, i.e., the increase in total body water and in total exchangeable sodium and the prob- 
ably disproportional increase in the amount of extracellular water, cannot be decided at present. However, these differences between the acromegalic and healthy subjects are similar to those observed between infants and adults $(19,25,26)$.

\section{SUMMARY}

The amount of total body water (antipyrine space) per $\mathrm{Kg}$. of body weight and per square meter of body surface, was significantly increased in a group of 18 acromegalic patients.

The amount of total exchangeable sodium in $\mathrm{mEq}$. per $\mathrm{Kg}$. of body weight, per square meter of surface area or per liter of total body water was also increased in the same patients.

The amount of extracellular water (inulin or thiosulfate spaces) per $\mathrm{Kg}$. of body weight or per square meter of surface area was higher in the acromegalic patients.

The apparent mean intracellular sodium concentration was higher in the acromegalic subjects.

\section{REFERENCES}

1. Bierring, E., and Nielsen, E., The composition of the tissues of albino rats treated with alkaline anterior pituitary extracts. Biochem. J., 1932, 26, 1015.

2. Lee, M. O., and Schaffer, N. K., Anterior pituitary growth hormone and the composition of growth. J. Nutrition, 1934, 7, 337.

3. Young, F. G., Growth and diabetes in normal animals treated with pituitary (anterior lobe) diabetogenic extract. Biochem. J., 1945, 39, 515.

4. Li, C. H., Simpson, M. E., and Evans, H. M., The gigantism produced in normal rats by injection of the pituitary growth hormone; III. Main chemical components of the body. Growth, 1948, 12, 39.

5. Li, C. H., Simpson, M. E., and Evans, H. M., Influence of growth and adrenocorticotropic hormones on the body composition of hypophysectomized rats. Endocrinology, 1949, 44, 71.

6. Whitney, J. E., Bennett, L. L., and Li, C. H., Reduction of urinary sodium and potassium produced by hypophyseal growth hormone in normal female rats. Proc. Soc. Exper. Biol. \& Med., 1952, 79, 584.

7. Glafkides, C. M., and Bennett, L. L., Reduction of urinary sodium and potassium of diabetic rats produced by hypophyseal growth hormone. Proc. Soc. Exper. Biol. \& Med., 1951, 77, 524.

8. Stein, J. D., Jr., Bennett, L. L., Batts, A. A., and $\mathrm{Li}, \mathrm{C}$. H., Sodium, potassium and chloride retention produced by growth hormone in the absence of the adrenals. Am. J. Physiol., 1952, 171, 587.

9. Batts, A. A., and Bennett, L. L., Effect of hypophyseal growth hormone $(\mathrm{GH})$ on the thiocyanate space and muscle electrolytes. J. Clin. Endocrinol., 1951, 11, 753.

10. Campbell, J., Hausler, H. R., Munroe, J. S., and Davidson, I. W. F., Effects of growth hormone in dogs. Endocrinology, 1953, 53, 134.

11. Soberman, R., Brodie, B. B., Levy, B. B., Axelrod, J., Hollander, V., and Steele, J. M., The use of antipyrine in the measurement of total body water in man. J. Biol. Chem., 1949, 179, 31.

12. Forbes, G. B., and Perley, A., Estimation of total body sodium by isotopic dilution. I. Studies on young adults. J. Clin. Invest., 1951, 30, 558.

13. Gaudino, M., Schwartz, I. L., and Levitt, M. F., Inulin volume of distribution as a measure of extracellular fluid in dog and man. Proc. Soc. Exper. Biol. \& Med., 1948, 68, 507.

14. Cardozo, R. H., and Edelman, I. S., The volume of distribution of sodium thiosulfate as a measure of the extracellular fluid space. J. Clin. Invest., 1952, $31,280$.

15. Brodie, B. B., Axelrod, J., Soberman, R., and Levy, B. B., The estimation of antipyrine in biological materials. J. Biol. Chem., 1949, 179, 25.

16. Schreiner, G. E., Determination of inulin by means of resorcinol. Proc. Soc. Exper. Biol. \& Med., 1950, 74, 117.

17. Newman, E. V., Gilman, A., and Philips, F. S., The renal clearance of thiosulfate in man. Bull. Johns Hopkins Hosp., 1946, 79, 229.

18. Ikkos, D., Luft, R., and Sjögren, B., The distribution of fluid and sodium in healthy adults. Metabolism, In press.

19. Friis-Hansen, B. J., Holiday, M., Stapleton, T., and Wallace, W. M., Total body water in children. Pediatrics, 1951, 7, 321.

20. Prentice, T. C., Siri, W., Berlin, N. I., Hyde, G. M., Parsons, R. J., Joiner, E. E., and Lawrence, J. H., Studies of total body water with tritium. J. Clin. Invest., 1952, 31, 412.

21. Ikkos, D., Ljunggren, H., Luft, R., and Sjögren, B In preparation.

22. Hurst, W. W., Schemm, F. R., and Vogel, W. C., Simultaneous determination of total body water by antipyrine and deuterium oxide; evaluation of the methods on edematous subjects. J. Lab. \& Clin. Med., 1952, 39, 36.

23. Nichols, G., Jr., Nichols, N., Weil, W. B., and Wallace, W. M., The direct measurement of the extracellular phase of tissues. J. Clin. Invest., 1953, 32, 1299.

24. Edelman, I. S., James, A. H., and Moore, F. D., Penetration of sodium and water into bone as measured with radiosodium and $\mathrm{D}_{2} \mathrm{O}$. Federation Proc., 1952, 11, 40.

25. Fellers, F. X., Barnett, H. L., Hare, K., and McNamara, $H$. ., Change in thiocyanate and sodium spaces during growth. Pediatrics, 1949, 3, 622.

26. Katcher, A. L., Levitt, M. F., Sweet, A. Y., and Hodes, H. L., Alterations of fluid and electrolyte distribution and renal function in diarrhea of infancy. J. Clin. Invest., 1953, 32, 1013. 